\title{
Chapter 9 \\ The Road of the German Book Praktische Analysis into Japanese Secondary School Mathematics Textbooks (1943-1944): An Influence of the Felix Klein Movement on the Far East
}

\author{
Masami Isoda
}

\begin{abstract}
Japan caught up with the Klein movement at time it occurred and translated the movement into Japanese to be shared immediately. However, incidents such as the huge earthquake in 1923 caused stagnations. Fruitful classroom experiments were done over the years, and mathematics subjects up to calculus were integrated into the mathematics Clusters I and II secondary school textbooks in 1943-44. The textbooks included praktische Analysis in relation to mechanical instruments. This paper shows, compared to some impact from the US, the clear influence of the von Sanden's Praktische Analysis on Japan. It also explains how the mechanics and kinematics approaches, known since the era of van Schooten (De Organica Conicarum Sectionum In Plano Descriptione, Tractatus. Geometris, Opticis; Præsertim verò Gnomonicis \& Mechanicis Utilis. Cui subnexa est Appendix, de Cubicarum Æquationum resolutione. Elzevier, Lugdunum Batavorum, 1646), served as missing link for integrating geometry and algebra into the concept of function in teaching in Japan during World War II.
\end{abstract}

Keywords Practical analysis · Mechanical instruments $\cdot$ Geometry $\cdot$ Algebra Calculus $\cdot$ Felix Klein

\footnotetext{
M. Isoda (更)

Center for Research on International Cooperation

in Educational Development, University of Tsukuba, Tsukuba, Japan

e-mail: isoda@criced.tsukuba.ac.jp 


\subsection{Background and Objective of This Paper}

One of the major tasks of the history of mathematics education is to clarify the current position of mathematics education by examining the viewpoints of past reforms, which include the transition of issues, objectives, and materials. One of the difficulties is the interpretation of curricular reform in the context of earlier periods. In particular, based on the Japanese interpretation of the new math movement, ${ }^{1}$ the secondary school curriculum was more oriented towards algebraic representation. Thus, current mathematics educators have never had a chance to study the mathematics that existed in the past. Historical mathematics before our times is, therefore, a kind of lost mathematics based on different conceptual frameworks, even though the technical terms look the same.

Reading and understanding historical textbooks gives the opportunity to relearn lost mathematics and recognize their viewpoint. The mathematics Clusters I and II textbooks from 1943 to 1944 (Grades 1 to 4, for 12- to 15-year-old students, Published from Secondary School Publisher $)^{2}$ for secondary school, ${ }^{3}$ were a decisive achievement under the influence of the Klein movement ${ }^{4}$ in the Far East, since starting with these books preliminary calculus became introduced into the mathematics curriculum of Japanese secondary schools. Even though published in the middle of World War II, the textbooks were very well organized and applied the principle of mathematization. Thus, they are usually referred to as the mirror to reflect the curriculum reform that was oriented towards mathematical activity. Indeed, after World

\footnotetext{
${ }^{1}$ Japanese New Math (Ministry of Education 1968) includes, as in other countries, the movement to introduce sets and structure. However, it also applied the principle of reorganizing mathematics as a spiral cycle of extension and integration to foster mathematical thinking using appropriate activities. It also added Freudenthal's (1968) mathematization idea, since in Japan similar ideas had existed already earlier (Nabeshima and Tokita 1957). The origin of this principle, i.e. the terminology of mathematization, can also be traced back to the guidebooks for the textbooks Clusters I and II.

${ }^{2}$ The books were published by the Secondary School Textbook Publisher on demand of the Ministry of Education. The authors were teachers and professors of the affiliate school of the Tokyo Higher Normal School which leads after graduation to Tokyo University of Literature and Science, and the Ministry.

${ }^{3}$ Until World War II, the Japanese school system was parallel, not linear, and has undergone a complicated process since 1872. In short, secondary schools, which used Clusters I and II textbooks, were preparatory schools for high schools, and high schools were preparatory schools for universities. The Clusters I and II textbooks were for exceptional and affluent students who were able to study at secondary schools. Compulsory education was limited to elementary and senior elementary school. Students normally went to senior elementary schools after the graduation from elementary schools, but exceptional students who had the availability to go to higher education went to secondary schools. Secondary and normal school teachers graduated from higher normal schools, high school teachers graduated from universities, and elementary school teachers from normal schools. Normal schools are a kind of vocational school after senior elementary school. Tokyo University of Science and Literature was the university for students who graduated from the Tokyo Higher Normal School which was the school for the graduated students of normal schools.

${ }^{4}$ Here, the Klein movement means the curriculum reform movement that took place up to World War II involving the integration using graphs of functions of different subjects such as arithmetic, algebra, and geometry into one mathematics culminating in calculus.
} 

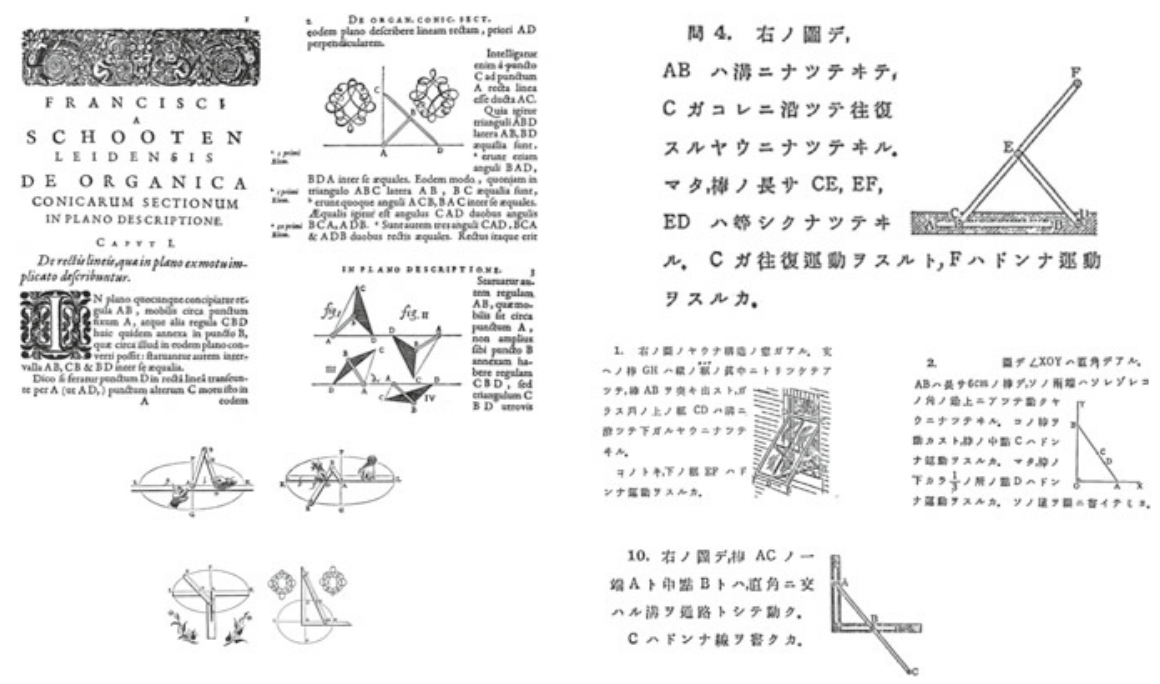

Fig. 9.1 Van Schooten (1646), excerpted from pp. 1-3, 26, 28, and 30, and Cluster II (1943), Vol. 3 (Grade 3 for 14 year olds), excerpted from pp. 2, 3, 4, and 27

War II, Japanese curriculum reforms developed appropriate mathematical activities (beginning in 1947), mathematical thinking (beginning in 1951), and mathematization (after the war and again in 2017). For current educators, however, it is difficult to understand these textbooks within the original meaning of the reform because it is based on lost mathematics. However, what is that lost mathematics in Clusters I and II? Several mathematics education research papers in Japan have examined this question. However, due to their brevity, the papers mainly focused on historical issues in the development of textbooks but did not provide an opportunity for current readers to learn about the lost mathematics itself.

In light of this situation, Masami Isoda and Maria Bartolini Bussi published (in Japanese) the Encyclopedia of Curve: Properties, History, and Construction (2009) in order to share the geometrical origin and algebraic transition of mathematics up to calculus (see Isoda 1996, 1998; Tall 2013). One finding in the book is the correspondence between the teaching sequences of Frans van Schooten's textbook (1646) and the Cluster II textbook (1943) regarding the same mechanical instruments (see Fig. 9.1).

The textbooks in Fig. 9.1, published almost 300 years apart, cannot be directly connected. During those 300 years, historical processes were developed and revised for reorganizing mathematics in mathematics textbooks. ${ }^{5}$ In the end, the same tasks and sequences may emerge that were earlier based on Euclid. Thus, the sequence in Fig. 9.1 can be understood as being based on Euclid. However, Clusters I and II did not

\footnotetext{
${ }^{5}$ The categories of mathematics textbooks used in schools after 1872 in Japan were developed in Europe under the influence of the French school system in the early 19th century (Schubring 2015). For the greater context see also: http://math-info.criced.tsukuba.ac.jp/museum/TGSW2015/.
} 
include Euclidean-geometric proofs even though they enhanced the demonstration and proving by students. Before Clusters I and II, geometrical proof and construction was employed in secondary school. To introduce content up until calculus, however, Clusters I and II used intuitive explanation with practical experiments using various instruments rather than exact proof. ${ }^{6}$

Even though the influence of Klein involves long historical processes, one piece of evidence of the missing link connecting Japan and Europe is Hans von Sanden's Praktische Analysis (1914). This paper aims to illustrate the significance of this missing link in order to understand the historical development of the Clusters I and II mathematics textbooks. These books show the influence of the Klein movement on the integration of subjects up to calculus into the curricula of the Far East, especially in Japan, but not only there. ${ }^{7}$

\subsection{The Influence of Klein on the Far East: The Case of Japan}

During the Meiji period (1868-1912), leading Japanese mathematicians studied in Europe $^{8}$ in countries such as UK, France, and Germany. Many of them studied in Germany and the Klein movement in Europe was well known since its earliest stage.

The state of mathematics in schools at that time was summarized at the Fifth International Congress of Mathematicians in Cambridge in 1912, when the Japanese sub-commission of the International Commission of the Teaching of Mathematics published the Report on the Teaching of Mathematics in Japan (see Fujisawa 1912/2017). In the attached Divisional Report II, after the preface of Fujisawa, Noriyuki Nishikawa, Professor at Tokyo Higher Normal School, already mentioned for the middle school the movement "to give the pupils elementary concept of function is most important as a direct aim in teaching of algebra" (Nishikawa 1912, p. 13). At that time, graphs and functions were recognized as content that bridged subjects such as arithmetic, algebra, and geometry. However, the curricular reform of 1911 only mentioned that they should be treated in teaching and not as a means of integration of subjects. The curriculum at that time was influenced by the first generation of

\footnotetext{
${ }^{6}$ In Cluster II, Vol. 4 (Grade 4 for 15-year-olds, which is the last grade), there were tasks involving proofs; however, exact bases for proving were not given in the textbook. In this context, it was possible for students to use intuitive or algebraic explanations.

${ }^{7}$ Japanese was one of the teaching languages in many parts of the Far East. More than 10,000 Chinese students studied in Japan from 1896 to 1906. Some of them were related with the Xinhai Revolution. Sun Yat-sen, the founder of the Republic of China, also studied in Japan. After World War II, in the Republic of Korea, the first textbooks for secondary school mathematics were Korean adopted editions of Clusters I and II.

${ }^{8}$ Before WW II, the newest achievements in mathematics were usually published in German and French. German was a necessary language for Japanese mathematicians, as were French and English.
} 
mathematicians who had studied in Europe, such as Dairoku Kikuchi, ${ }^{9}$ who finally became the minister of education, and his colleague, Rikitaro Fujisawa. ${ }^{10}$ Fujisawa insisted in the independence of every sub-discipline in mathematics to keep their theoretical differences. In his context, he could not share the reform conception of integrating the sub-disciplines.

It was against this conservative situation that under the order of the Japanese Ministry of Education, Gaisaburo Mori translated Otto Behrendsen and Eduard Götting's Lehrbuch der Mathematik nach Modernen Grundsätzen $(1908,1911)$ for secondary and high school teachers from German into Japanese in 1915-1916. To promote the reform movement throughout Japan, Motoji Kunieda and his colleagues at the Tokyo Higher Normal School established the Japan Society of Secondary School Mathematics ${ }^{11}$ in 1919 . The society shared the reform movement at every annual meeting as a national issue. Secondary school teachers presented their research on curriculum innovation at these meetings and it was published in the society's journal.

In 1921, Tsuruichi Hayashi, the first president of the society, translated Klein's 1904-1905 lectures for secondary school mathematics as the first book (1907) of the University of Göttingen lecture series. Kinosuke Ogura supervised the translation of Leçons d'Algèbre Elémentaire by Bourlet (1909) in 1919 and translated Praktische Analysis by von Sanden (1914) in 1928. Before these translations, a limited number of mathematicians, teachers and students had read the original books. The reform's intentions reached every secondary school teacher thanks to these Japanese editions. Hayashi recommended in his preface to Klein's book (1907) that secondary school teachers read both books by Behrendsen and Götting and by Bourlet. Both books treat functions and calculus in their later chapters, which follows the goals of both textbooks. The book by Bourlet was dedicated to algebra. The book by Behrendsen and Götting treated geometry, algebra (including coordinates, graphs, and simple construction), trigonometry, calculus with functions for Gymnasium, and projection. ${ }^{12}$

While the book by Behrendsen and Götting was written for secondary schools (Gymnasium), the book by von Sanden (1914) was written for undergraduate stu-

\footnotetext{
${ }^{9}$ Kikuchi was trained according to the tradition of Wasan, the Japanese mathematics of the Edo era. He received a top score in mathematics at Cambridge. Later, he became the president of the University of Tokyo and University of Kyoto and became the Minister of Education. Fujisawa studied in Germany before the Klein reform.

${ }^{10}$ Kikuchi and Fujisawa were founders of the mathematics department of the University of Tokyo and Fujisawa was an advisor of the next generations. The second generation of mathematicians related to this reform, such as Mori, Hayashi, and Kunieda, graduated mostly from the University of Tokyo and worked at other universities and schools. Hayashi had been a professor of the Tokyo Higher Normal School until the establishment of the mathematics department of the Tohoku Imperial University. Many of them had opportunities to study in Europe. Mathematicians in the University of Tokyo such as Teiji Takagi, a member of the first Fields' Award committee, also studied in Germany, but did not lead the reform himself, even though he was familiar with the reform. He merely referenced the existence of the movement in the preface to his secondary school textbooks.

${ }^{11}$ It was the predecessor of the Japan Society of Mathematical Education.

${ }^{12}$ Gymnasium in Germany corresponds to secondary and high schools in Japan before WW II. Clusters I and II for Japanese secondary schools corresponds to the first half of the German Gymnasium.
} 
dents based on his experience at the University of Göttingen. ${ }^{13}$ It treated integration of algebra and geometry for calculus with graphs of functions, construction with geometry, and plotting points as the sets of numerical solutions. This paper discusses how von Sanden's book influenced the integration of subjects up to calculus at secondary schools, comparing it with Hamley's (1934) Relational and Functional Thinking in Mathematics.

\subsection{Integration of Algebra and Geometry with Mechanical Instruments}

Minoru Kuroda, a teacher at the affiliated secondary school of the Tokyo Higher Normal School, was the first mathematics educator who studied abroad. He studied in Göttingen and returned to Japan in 1913. He contributed to the establishment of the Japan Society of Secondary Mathematical Education and to its proposal for curriculum reform in 1919. Because in 1923, while Kuroda and others planned the new curriculum, the metropolitan region of Tokyo was hit by a strong earthquake and destroyed by fire, the Ministry of Education was not able to enact the curricular reform. Even in this situation, several reform ideas from Kuroda's articles (1927) for the integration of disciplines, such as those shown in Fig. 9.2, had been kept from burning (see Isoda and Bartolini Bussi 2009). Because of this disaster, Japanese mathematicians spent several decades working on the experimental design of the integration of subjects up to calculus, including the relation between algebra and geometry using the graphs of functions. In the middle of World War II, they finally developed Clusters I and II (for 12- to 15-year-old secondary school students) following the principle of mathematization (1943-1944).

The influences of reform movements in Japan came not only from Germany but also from the UK and the US. Indeed, the Japanese respected John Perry, who began his professional career as a mathematician in Japan at the beginning of Meiji era. He became the president of the Physical Society of London in the early 20th century, and his works were also translated into Japanese. Perry also emphasized practical mathematics, even though he did not enhance the integration of the subjects including calculus using the function concept as Klein did. Experimental methods developed by Eliakin Hastings Moore in the US were also well known. Because the Japanese were able to practice their experimental research for several decades, reforms were

\footnotetext{
${ }^{13}$ The books were published after the publication of Felix Klein's world-famous book Elementarmathematik vom Höheren Standpunkte aus (1908-1928). The 1908 edition was polycopied as handwriting. It was well read by Japanese mathematicians such as Ogura who introduced it in Japanese in the Japanese journal Tokyo Buturigakko Zassi (1909, Vol. 18). Later, both Ogura (1950) and Shokichi Iyanaga, President of ICMI (1975-1978), wrote about what they had learned. Iyanaga wrote about his impressions upon reading it as a high school student on the book for Ogura's 70th Anniversary Celebration (1956). Klein (1908) was translated into English (1924) and retranslated into Japanese (Toyama; 1959-1961) which did not include the Vol. 3 of Klein (2016).
} 

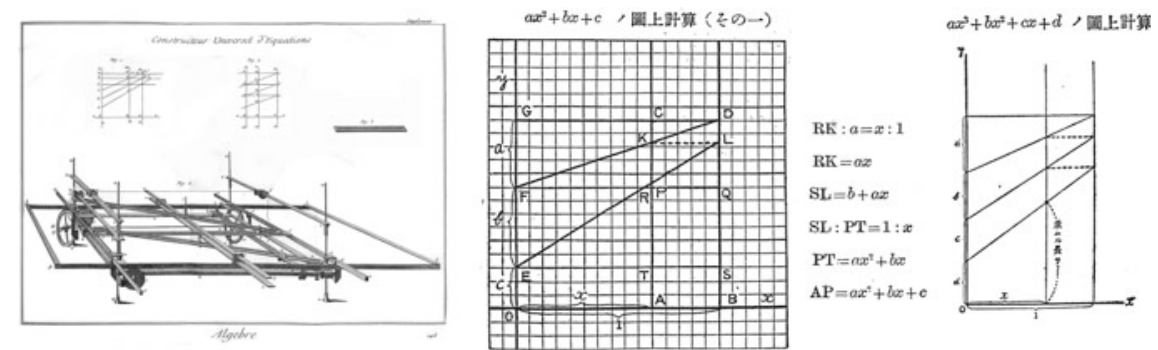

Fig. 9.2 Mechanical instruments to draw the graph of polynomial functions, bridging geometry and algebra in Diderots's Encyclopedia; cited in Vol. 19, of the Supplements (Diderot 1776): Equation, pp. 832-840 and in Vol. 33. Planches (Diderot 1777) Algebrae, p. 18, Constructeur Universel Equations, p. 14-E33-Nr. 33. The explanation on the right is from Kuroda (1927, p. 299) (Minoru Kuroda was the first mathematics educator who had the opportunity to study in Europe. This book was published posthumously in 1927 (he passed away in 1922) as a part of his collected publications. One third of the content was based on what he learned in Germany in 1910-1911 and in England and the US in 1912. The rest was his lectures at the open classes done by other teachers who promoted reform ideas and tentative plans for curricular reforms. His textbooks were mostly familiar textbooks that included the ideas of new movements within the limitation of the old curriculum. After he came back to Japan from abroad, he became a professor at the Tokyo Higher Normal School and wrote secondary school textbooks based on what he learned and what he experimented with at the affiliate secondary school of the Tokyo Higher Normal School.).

achieved by the third generations, and thus, they also knew the work of Hamley ${ }^{14}$ (1934), which was also translated into Japanese by Aoki (1940).

Figure 9.2 shows an example for the integration of geometry and algebra for functions from Diderot (1776-1777) which is from Johann Andreas von Segner (1704-1777). He was born in Hungary, and in 1735 he became the first professor of mathematics at the newly founded University of Göttingen. This mechanism also appeared in von Sanden (1914). Kuroda (1927) explained the idea in the context of the reform movement proposed by Klein, which integrates geometry and algebra via graphs of functions.

\footnotetext{
${ }^{14}$ The Japanese translation of Relational and Functional Thinking in Mathematics was published in 1940 before Clusters I \& II. The translator Seisiro Aoki was a scholar at the Tokyo Higher Normal School (University of Tsukuba). Before Cluster I and II, several developments of the curriculum had been done nationally since the establishment of the Japan Society of Secondary School Mathematics in 1919, and three curriculum plans were proposed in Tokyo, Osaka, and Hiroshima under that society (1940; see such as Mathematics Research Committee of the Affiliate School of the Tokyo Higher Normal School 1940 and Koga, S. 1940). Professors of the Tokyo Higher Normal Schools and teachers at the affiliated secondary school embedded their long-term experiments of lesson studies at their affiliated secondary school and others into the textbooks which synchronized with other countries such as Germany, England and USA.
} 

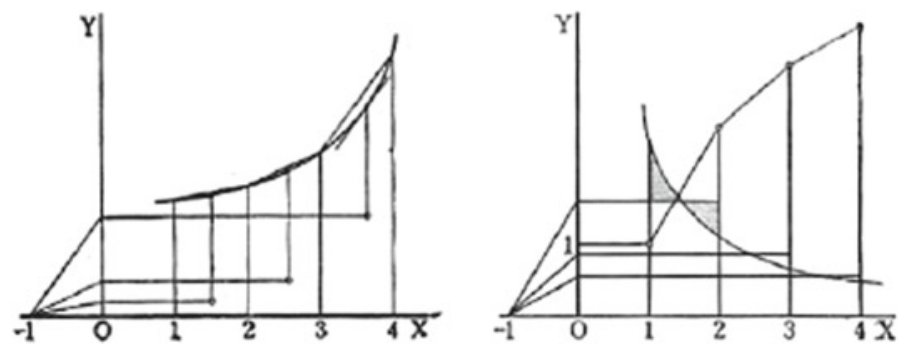

Fig. 9.3 Drawing the derivative and the primitive function from the given graph in Mathematics Cluster I (1944), Vol. 4 (Grade 4 for 15-year-olds), p. 9

\subsection{Embedded German Praktische Analysis in the Japanese Textbook for Cluster I (1943)}

The Japanese textbooks for Clusters I and II were the first textbooks in Japan that integrated arithmetic, algebra, and geometry via the concept of function and graphical representations including calculus. Figure 9.3 is a clear example that shows the ideas in von Sanden (1914) that adopted for the Japanese curriculum for 15-year-old students for realizing integration up to calculus.

Figure 9.3 can also be seen in von Sanden (1914, pp. 97 and 103). ${ }^{15}$ According to the Japanese translators and editors, Ogura and Kondo (1928), Klein established the course for praktische Analysis at the University of Göttingen in 1904. Von Sanden became a lecturer at Göttingen and published the book based on his lecture courses. Ogura explained in the Japanese edition that Praktische Analysis was the best book in this area because of this origin. In addition to the English translation by Levy (1923), the Japanese edition was an adaptation by Ogura due to his addition of content and footnotes to make it more easily understood. ${ }^{16}$ Thus, various efforts have been made to adapt the ideas of von Sanden from university mathematics into Japanese secondary school mathematics.

\subsection{The Influence of Klein: Germany or Origins from UK and US?}

Since the Japanese achievements were not only influenced by Germany but also the UK and the US, we can at first not be sure whether the origin of Fig. 9.3 can be

\footnotetext{
${ }^{15}$ Figure 2 was also included in Sanden (1914, pp. 45-48) but was not in Clusters I and II.

${ }^{16}$ Before translating von Sanden, Ogura had already published Approximate Solution Using Diagrams and Graphs (1923) in Japanese. This implicates that he did not completely translate from the English Edition. His translated books usually including many revisions and enlargements based on his own studies.
} 
attributed to von Sanden or not. However, there is clear positive evidence that it originated in Germany when we compare it with the discussions of Hamley (1934):

Klein has said that "for a thorough and fruitful treatment of the function concept, the fundamentals of mechanics may be taken as a necessary material." With this opinion we are in full agreement. It is not clear whether Klein restricts the term "mechanics" to kinematics, or whether he also includes kinetics, which involves the concept of mass. In our course, we have confined our attention almost exclusively to kinematics, not because of any unwillingness to include kinetics, but because the space-time concept provides us with all the functional material we need. (p. 112)

Klein emphasized mechanics as the foundation of the treatment of the function concept. However, Hamley explained the space-time concept as an alternative to kinematics. Mechanics here was basically represented by geometry. Klein propagated the integration of algebra and geometry for teaching calculus. Hamley introduced the space-time concept, which can be represented by numbers and algebra without geometry. Even though the space-time concept is normally used for functions in algebra, according to Hamley's claim, Fig. 9.3 could not be explained because it does not depend only on space-time. This is how we can affirm that Klein and von Sanden's view is shown in Fig. 9.3.

Of course, we also recognize that space-time situations appear in the introduction of calculus in Cluster I. However, in the case of Cluster I, differentiation and integration are solved using Fig. 9.3 before introducing the algebraic operations of differentiation and integration. ${ }^{17}$ Before algebraic operations, the idea of the fundamental theorem of calculus is introduced, and space-time situations are solved by geometric operations as shown in Fig. 9.3. Additionally, in Cluster II, which is taught in parallel with Cluster I, before learning calculus, kinematics is applied as visualized in Fig. 9.1.

\subsection{Conclusion}

Due to the comparison between the books by von Sanden and Hamley, the integration of the sub-disciplines arithmetic, algebra, and geometry including calculus in Japanese school mathematics, which was originally proposed by Klein, is evidenced in Clusters I and II. We showed the book by von Sanden to be a missing link to the currently lost mathematics, which we never learn up to university in these days.

This point of discussion is summarized as shown in Fig. 9.4.

Figure 9.4 shows the basic framework for Clusters I and II. However, the era of the US occupation of Japan after WW II resulted geometry with constraction was

\footnotetext{
${ }^{17}$ The treatment of graphs involving space-time also appeared in Hayashi's (1921) translation of Klein (1907). The salient point is whether there is a reference to geometry or not. Cluster I and II show the efforts that have been made to adapt the ideas of von Sanden from university mathematics into Japanese secondary school mathematics based on geometry. Hamley focused on space-time and did not treat geometry as the basis of functions.
} 


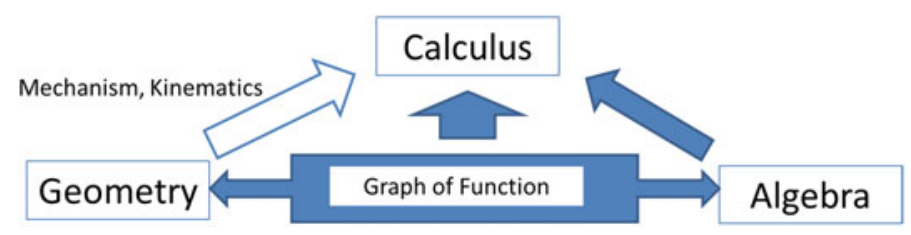

Fig. 9.4 Mechanics and kinematics as a missing link for teaching the integration of the subdisciplines including calculus

reintroduced but the functions up to calculus were following space-time framework. ${ }^{18}$ There were two reasons. The first reason was the transforming of the school system from parallel to linear. The curriculum for secondary schools was divided into one part for new junior high and another for senior high schools, and student populations were redefined. Compulsory education ended with junior high schools, at 15 years old, with the curriculum reaching proofs in geometry and quadratic functions. Senior high schools were divided into schools depending on student achievement, from preparatory schools for the universities to various vocational schools. The second reason was the New Math. Algebraic mathematics including vectors and matrices were introduced, and construction and trigonometry in geometry became restricted. In this context, the direction from geometry to calculus in Fig. 9.4 by kinematics and mechanics becomes the missing link to understand Clusters I and II for our period.

Currently, technology such as dynamic geometry software enables anyone in the world to approach mechanisms and kinematics of Figs. 9.1, 9.2 and 9.3. For example, Isoda (2008) developed e-textbooks ${ }^{19}$ for Fig. 9.1 and engaged in lesson study to demonstrate their significance in mathematics education (see Bartolini Bussi et al. 2010). The objectives of lesson study with e-textbooks are firstly to demonstrate the close relationship between elementary geometry and mechanisms and recognize that elementary geometry provides the intuition for reasoning about mechanisms, and secondly, to recognize the difference between the mathematical systems for the solutions for the loci of the mechanism in Fig. 9.1 using elementary geometry, analytic geometry and vectors, and so on. Analytic geometry usually uses the conclusions of geometric reasoning in order to algebraically prove the equation for the algebraic solution; however, this is the adaptation of the conclusion of elementary geometry.

\footnotetext{
${ }^{18}$ The General Headquarters of the Allied Forces governing Japan from 1945 to 1953 supervised and directed the Japanese curricular reform according to the principle of activity and appreciation especially for compulsory education (Makinae 2011), which is one of the bases for the current Japanese problem-solving approach. This approach is well known as a part of the recent lesson study movement aimed at developing children who learn mathematics by and for themselves.

${ }^{19}$ The lesson study video clips (Isoda 2008; Isoda \& Yamamoto 2009; Isoda 2010) with Dr. Yuriko Yamamoto Buldin for graduate students of the Universidade Federal do Rio de Janeiro can be seen at: http://math-info.criced.tsukuba.ac.jp/museum/dbook_site/dbookEng_with_DGraph_2010 0402/CDImageEnglish/Schooten-Monbsho-VTR/SchootenVTR/index.html. A Japanese textbook with simulation can be seen at: http://math-info.criced.tsukuba.ac.jp/museum/dbook_site/Schooten OnWeb1/Schooten1/index.html. Van Schooten's e-textbook requires Adobe Flash Player; click the bottom to see the video (flv) and to use the simulation.
} 
From the perspective of elementary geometry, the ways of reasoning of analytic geometry include tautology. ${ }^{20}$ Mechanisms and kinematics provide intuition that is synchronized with elementary geometry which includes reasoning through the embedded figures of the theorem but is not always synchronized with reasoning using the form of algebra and calculus.

This paper concludes that the contents of the missing link between calculus and geometry was specified by kinematics and mechanics and that the link was one of the key ideas to be considered in the curricular integration of the subjects of arithmetic, algebra, and geometry for calculus and shows good evidence of what the Klein movement achieved in the Far East up until WW II. This paper also discussed how the Klein movement was introduced. However, it does not deeply describe how the Japanese worked on producing their own original adaptation through the decades until the production of the textbooks for Clusters I and II at the secondary level.

Acknowledgements This research was supported by JSPS (KAKENHI-Kiban A) 26245082 and MEXT (KAKENHI-Tyousenteki Hoga) 16K13568. The author deeply acknowledges Dr. Gert Schubring at the University of Bielefeld and Dr. Michael Neubrand at the University of Oldenburg, who gave him fruitful suggestions, and Dr. Aira Yap and Mr. Guillermo Bautista at the University of the Philippines, who technically supported his English writing.

\section{References}

Bartolini Bussi, M., Taimina, D., \& Isoda, M. (2010). Concrete models and dynamic instruments as early technology tools in classrooms at the dawn of ICMI: From Felix Klein to present applications in mathematics classrooms in different parts of the world. ZDM Mathematics Education, 42(1), 19-31. https://doi.org/10.1007/s11858-009-0220-6.

Behrendsen, O., \& Götting, E. (1908). Lehrbuch der Mathematik nach modernen Grundsätzen. Leipzig: Teubner.

Behrendsen, O., \& Götting, E. (1911). Lehrbuch der Mathematik nach modernen Grundsätzen (2nd ed.). Leipzig: Teubner.

Behrendsen, O., \& Götting, E. (translated and edited by G. Mori) (1915-1916). Lehrbuch der Mathematik nach modernen Grundsätzen (Vols. 1 and 2). Tokyo: National Textbook Dealer (in Japanese. Japanese title: Shinsyugi Suugaku).

Bourlet, C. (1909). Leçons d'Algèbre Elémentaire (6e éd). Paris: Librairie Armand Colin.

Bourlet, C. (translated by M. Takebe, edited by K. Ogura) (1919). Leçons d'Algèbre Elémentaire. Tokyo: Sankaido (in Japanese. Japanese title: Syotou Daisuugaku).

Diderot, D., et al. (1776-1777). Supplément à l'Encyclopédie ou Dictionnaire raisonné des sciences, des arts et des métiers (Vols. 19 and 33). Paris/Amsterdam: Panckoucke, Stoupe, Brune/M. M. Rey.

Freudenthal, H. (1968). Why to teach mathematics so as to be useful. Educational Studies in Mathematics, 1(1), 3-8. https://doi.org/10.1007/BF00426224.

Fujisawa, R. (1912, reprinted 2017). Summary report on the teaching of mathematics in Japan, 1912. Tokio: [Japanese Sub-Commision of the International Commission on the Teaching of Mathematics], 1912.

\footnotetext{
${ }^{20} \mathrm{http} / / /$ math-info.criced.tsukuba.ac.jp/software/up.Schooten-Descartes/Schooten-DescartesHTE M4rio.files/frame.htm.
} 
Hamley, H. R. (1934). Relational and functional thinking in mathematics. New York: Columbia University.

Hamley, H. R. (translated and commented by S. Aoki) (1940). Relational and functional thinking in mathematics. Tokyo: Monasu (in Japanese. Japanese title: Kansuuteki Shikouno Shinri).

Isoda, M. (1996). The development of language about function: An application of van Hiele Levels. In L. Puig \& A. Gutierrez (Eds.), Proceedings of the 20th Conference of the International Group for the Psychology of Mathematics Education (Vol. 2, pp. 105-112). Valencia: University of Valencia.

Isoda, M. (1998). Developing the curriculum for curves using history and technology. In W. Yang, et al. (Eds.), Proceedings of the Third Asian Technology Conference in Mathematics (pp. 82-89). Tokyo: Springer.

Isoda, M. (2008). Van Schooten (e-textbook) used for the lesson study workshop on the IV Colóquio de História e Tecnologia no Ensino da Matemática. retrived August 25, 2018 from http://mathin fo.criced.tsukuba.ac.jp/software/dbook/video/Schooten1646-Isoda2008/Schooten/index.html.

Isoda, M. (2010). Van Schooten and Japanese Textbook with movie (flv)(e-textbook embeded Lesson Study Video on van Schooten, F. (1646). De Organica Conicarum Sectionum In Plano Descriptione, Tractatus. Elzavier) retrived August 25, 2018 from http://mathinfo.criced.tsukuba.ac.jp/museum/dbook_site/dbookEng_with_DGraph_20100 402/CDImageEnglish/Schooten-Monbsho-VTR/SchootenVTR/index.html.

Isoda, M., \& Bartolini Bussi, M. (2009). Encyclopedia of curve: Properties, history and construction. Tokyo: Kyoritsu (in Japanese. Japanese title: Kyokusen no Giten: seishitsu, rekishi, sakuzuhou).

Isoda, M., \& Yamamoto, Y. B. (2009). Challenges of Lesson Study in UFRJ on IV HTEM: Descartes' Dream with van Schooten, Using Historical Sources on e-textbook, Keynote lecture at V Colóquio de História e Tecnologia no Ensino da Matemática (V HTEM). Retrived August 25, 2018 from http://mathinfo.criced.tsukuba.ac.jp/software/up.Schooten-Descartes/Schooten-D escartesHTEM4rio.files/frame.htm.

Iyanaga, S. (1956). The road of Dr. Ogura. In Ogura's 70 years-old Celebration Committee (Ed.), History of science and science education (pp. 3-6). Tokyo: Dainihon.

Klein, F. (1908). Elementarmathematik vom höheren Standpunkte aus (Handwriting ed.). Berlin: Springer.

Klein, F. (1924). Elementary mathematics from an advanced stand point: arithmetic, algebra, analysis. New York: Dover.

Klein, F. (2016). Elementary mathematics from a higher standpoint (Vols. 1, 2 translated by G. Schubring; Vol. 3 translated by M. Menghini \& A. Baccaglini-Frank). Berlin: Springer.

Klein, F. (edited by Schimmack, R.) (1907). Vorträge über den mathematischen Unterricht an den höheren Schulen. Leipzig: Teubner.

Klein, F. (edited by Schimmack, R., translated by M. Takebe \& T. Hayashi, edited, commented and enlarged by T. Hayashi) (1921). Vorträge über den mathematischen Unterricht an den höheren Schulen. Tokyo: Dainihon (in Japanese. Japanese title: Doitsuni Okeru Suugakukyouiku, Mathematics Education in Germany: Lectures of Felix Z).

Klein, F. (translated by Toyama, H.) (1959-1961). Elementary mathematics from an advanced stand point: arithmetic, algebra, analysis. v1-4. Tokyo: Syoko Syuppan/Tokyo Syoseki. (in Japanese. Japanese Title: Takai Tachibakaramita Syotou Suugaku).

Kuroda, M. (1927). New trends of mathematics education. Tokyo: Baifukan (in Japanese).

Makinae, N. (2011). The origin of the term "Appreciation" in mathematics education in postwar educational reform period: through the analysis of GHQ/SCAP records. Journal of Japan Society of Mathematical Education: Mathematics Education, 93(5), 2-11 (in Japanese).

Mathematics Research Committee of the Affiliate School of the Tokyo Higher Normal School. (1940). A report of the mathematics curricula reform committee on the Japan society of secondary school mathematics. Mathematics Education, 28, 27-46. Tokyo: Affiliate School of the Tokyo Higher Normal School (written in Japanese). 
Ministry of Education (1968). Course of study for elementary school matematics. Tokyo: Ministry of Education.

Nabeshima, N., \& Tokita, Y. (1957). Secondary school mathematics education research. Tokyo: Dainihon (in Japanese).

Nishikawa, N. (1912). The teaching of mathematics in middle school. In Japanese Sub-Commission on the International Commission on the Teaching of Mathematics (Ed.), Divisional reports of the teaching of mathematics of Japan: Being a series of reports prepared by the division of the Japanese Sub-commission of the international commission on the teaching of mathematics. In Report on the teaching of mathematics in Japan (prepared by Japanese Sub-Commission of the International Commission of the Teaching of Mathematics) (pp. 1-39). Tokyo: Tokyo University of Literature and Science.

Ogura, K. (1923). Approximate solution using diagrams and graphs. Tokyo: Sankaido (in Japanese. Japanese title: Zu oyobi keisan zuhyou).

Ogura, K. (1950). Reminiscence as a mathematician. Tokyo: Kawaide.

Secondary School Textbook Publisher. (1943). Clusters I for secondary school mathematics grade 3. Tokyo: Secondary School Textbook Publisher (in Japanese).

Secondary School Textbook Publisher. (1944). Clusters II for secondary school mathematics grade 4. Tokyo: Secondary School Textbook Publisher (in Japanese).

Schubring, G. (2015). Hermeneutics of historical mathematics textbooks. Retrieved from http://m ath-info.criced.tsukuba.ac.jp/museum/TGSW2015/copy_of_ppt_Gert20151116.pdf. Accessed February 5, 2018.

Koga, S. (1940). A news of the mathematics curricula research committee for the 22nd annual meeting of the Japan society of secondary school mathematics. School Mathematics, 39, 61. Hiroshima: Affiliate School of the Hiroshima Higher Normal School (written in Japanese).

Tall, D. (2013). How human learn to think mathematically: Exploring the three worlds of mathematics. New York: Cambridge University Press.

van Schooten, F. (1646). De Organica Conicarum Sectionum In Plano Descriptione, Tractatus. Geometris, Opticis; Prasertim verò Gnomonicis \& Mechanicis Utilis. Cui subnexa est Appendix, de Cubicarum Aquationum resolutione. Lugdunum Batavorum: Elzevier.

von Sanden, H. (1914). Praktische analysis. Leipzig: Teubner.

von Sanden, H. (translated and edited by H. Levy) (1923). Practical mathematical analysis. London: Methuen.

von Sanden, H. (translated, edited and enlarged by K. Ogura \& T. Kondo) (1928). Praktische Analysis. Tokyo: Sankaido (in Japanese. Japanese Title: Jituyou Kaisekigaku).

Open Access This chapter is licensed under the terms of the Creative Commons Attribution 4.0 International License (http://creativecommons.org/licenses/by/4.0/), which permits use, sharing, adaptation, distribution and reproduction in any medium or format, as long as you give appropriate credit to the original author(s) and the source, provide a link to the Creative Commons license and indicate if changes were made.

The images or other third party material in this chapter are included in the chapter's Creative Commons license, unless indicated otherwise in a credit line to the material. If material is not included in the chapter's Creative Commons license and your intended use is not permitted by statutory regulation or exceeds the permitted use, you will need to obtain permission directly from the copyright holder.

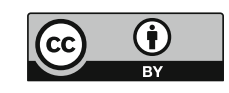

